УДК 338.45:658:316.422

JEL classification: L26, M21,O31, O32, O33

Чан Сі Цо

ORCID ID: 0000-0003-2945-5220

Київський наџіональний університет імені Тараса Шевченка

\title{
РОЗВИТОК МЕТОДІВ ІНТЕГРАЛЬНОЇ ОЦІНКИ РІВНЯ ІННОВАЦЙНОГО ПОТЕНЦІАЛУ КОМПАНІЙ
}

\section{DEVELOPMENT OF METHODS FOR INTEGRAL ASSESSMENT OF THE LEVEL OF INNOVATION POTENTIAL OF COMPANIES}

Досліджено існуючі методи оцінки інноваційного потенціалу компаній. Мета статті полягає в обтрунтуванні теоретичних засад і розробиі методологічного підходу до інтегральної оцінки інноваційного потенціалу компаній. Аналітичний огляд публікащій з даної проблеми вказує на необхідність забезпечення системного бачення вказаної проблеми на якісно новому рівні. Актуальність статті визначається необхідністю підвищення конкурентоспроможності компаній в ринкових умовах на засадах інтегральної оцінки наявного інноваційного потенціалу. Визначені закономірності і основні напрямки розвитку інноваційного потенціалу компаній. Показана особлива роль інноваційного потенціалу в діяльності компаній $i$ його взаємозв'язок із загальним розвитком компанії. Узагальнено основні складові інноваційного потенціалу компанії як сукупність різних ї̈ потенціалів. Встановлено важливе значення методів оцінки інноваційного потенціалу в системі управління компанією. Проаналізовано методи оцінки інновачійного потенціалу компаній та запропоновано основні напрямки їх вдосконалення. Визначено иілий ряд загальних вимог, яким повинні відповідати методи оцінки інноваційного потенціалу компаній, а також проведено порівняльний аналіз на відповідність цим вимогам розглянутих методів. Удосконалена класифікація індикаторів оцінки інноваційного потенціалу компаній. Уточнені методичні аспекти щцодо вибору приватних показників оцінки інноваційного потенціалу компаній. Розроблений алгоритм комплексної оцінки інновачійного потениіалу компаній. Удосконалена система індикаторів оиінки структурних складових інноваційного потенціалу компанії. Запропоновано розподіл інтервалів значень, щзо характеризують рівень інноваційного потенціалу компаній. Удосконалено підходи до інтегральної очінки інноваційного потенціалу, спрямовані на розвиток, нарощування $і$ відтворення інноваційного потенціалу, як основи інноваційного розвитку компаній. Запропоновано методичний підхід до інтегральної оцінки рівня інновачійного потенџіалу компаній, який побудований з урахуванням функиіональної залежності виділених структурних елементів інноваційного потенцііалу.

Ключові слова: інноваційний потенціал, компанії, показники, оцінка, ресурси

The existing methods for assessing the innovative potential of companies are studied. The purpose of the article is to substantiate the theoretical foundations and develop a methodological approach to the integral assessment of the innovative potential of companies. An analytical review of publications on this issue indicates the need to provide a systemic vision of this problem at a qualitatively new level. The relevance of the article is determined by the need to improve the competitiveness of companies in market conditions on the basis of an integral assessment of the existing innovative potential. The patterns and main directions of development of the innovative potential of companies are 
determined. The special roles of innovative potential in the activities of companies and its relationship with the general development of the company are shown. The main components of the company's innovative potential are summarized as a combination of its various potentials. The importance of methods for assessing innovative potential in the company management system has been established. Methods for assessing the innovative potential of companies are analysed and the main directions for their improvement are proposed. A number of general requirements have been identified that must be met by methods for assessing the innovative potential of companies, and a comparative analysis has been carried out for the compliance of the considered methods with these requirements. The classification of indicators for assessing the innovative potential of companies has been improved. The methodological aspects of the choice of private indicators for assessing the innovative potential of companies have been clarified. An algorithm for a comprehensive assessment of the innovative potential of companies has been developed. The system of indicators for assessing the structural components of the company's innovative potential has been improved. The distribution of the intervals of values characterizing the level of innovative potential of companies is proposed. Approaches to the integrated assessment of innovative potential are improved, aimed at developing, building and reproducing innovative potential as the basis for innovative development of companies. A methodological approach to the integral assessment of the level of the innovative potential of companies is proposed, which is built taking into account the functional dependence of the selected structural elements of the innovative potential.

Keywords: innovative potential, companies, indicators, assessment, resources.

Вступ. В умовах реформування української економіки, заснованої на знаннях, все більш актуальними є завдання, пов'язані з розробкою нових підходів до вирішення проблем інноваційного розвитку компаній на основі адекватних методів інтегральної оцінки та управління рівнем інноваційного потенціалу на мікро- і макрорівнях. У зв’язку з цим виникає потреба в теоретичному обгрунтуванні змісту структурних елементів інноваційного потенціалу компаній з позицій їх взаємозв'язків і взаємодії під впливом факторів зовнішнього і внутрішнього середовища. Доцільно також запропонувати методичний підхід до інтегральної оцінки рівня інноваційного потенціалу компанії з урахуванням функціональної залежності виділених структурних елементів інноваційного потенціалу.

Нині інноваційному потенціалу компаній присвячується все більше наукових робіт, що говорить про його зростаючу роль в економічному розвитку країни. Розробляються методики оцінки інноваційного потенціалу компаній, підходи до його дослідження, класифікації спеціальних показників (М. Антікайнен, М. Мякіпя, М. Ахонен, Е. Енкель, О. Гассман, Х. Чесбро, Е. Хельфат, Дж. Б. Квін) [1-3]. Проте єдиного методологічного підходу до оцінки рівня інноваційного потенціалу поки не сформувалося. Так, в європейських країнах прийнято оцінювати інноваційний потенціал компаній на основі результативного 
підходу (Х. В. Чесбро, В. Швердтнер, Р. Зіберт, М. Буссе, У. Фрайзінгер, Ф. Мікеліно А. Каммарано, Е. Ламберті, М. Капуто, Дж. Вест, А. Салтер, В. Ванхавербеке) [4-7], в Україні інноваційний потенціал підприємств оцінюють з позиції ресурсного підходу, сутність якого полягає в аналізі ефективності їх діяльності при використанні можливих ресурсів.

В цілому аналіз наукових джерел, присвячених питанням оцінки й управління інноваційним потенціалом показує, що нині практично відсутні теоретико-методичні положення, пов'язані 3 розробкою методів інтегральної оцінки рівня інноваційного потенціалу компаній для досягнення стратегічних цілей їх інноваційного розвитку.

Постановка завдання. Мета статті полягає в обгрунтуванні теоретичних засад і розробці методологічного підходу до інтегральної оцінки інноваційного потенціалу компаній.

Методологічною основою статті $\epsilon$ комплекс діалектичних принципів, що дозволили виявити сутнісні характеристики методів оцінки інноваційного потенціалу компаній, форми їх прояву і тренди розвитку. Дослідження проводилося 3 використанням системного, процесного i структурно-функціонального підходів, методів порівняльного аналізу, дедукції й індукції, узагальнення, експертних оцінок, економікоматематичних та економіко-статистичних методів.

Результати дослідження. Об'єктивна реальність, обумовлена дією ринкових законів, призводить до невпинного зростання конкуренції на всіх стадіях виробництва. Для того, щоб вижити в нелегких умовах компаніям необхідно постійно дбати про підвищення своєї конкурентоспроможності. Розвиток компаній i підвищення або підтримання на необхідному рівні конкурентоспроможності в ситуації безперервної взаємодії з динамічним зовнішнім середовищем можливо за рахунок активної інноваційної діяльності.

У цьому зв'язку виникає необхідність використання методів, що досліджують стан фінансової стійкості компанії, відповідно до якого розробляються стратегії і цілі управління. Методичне забезпечення повинно бути побудовано на комплексній оцінці діяльності компаній, виявлення трендів їх розвитку, аналізі динаміки основних показників функціонування компаній для реалізації принципів системного підходу в управлінні і регуляції взаємодії між його частинами таким чином, щоб забезпечувалася узгодженість у процесах, не виникало дисбалансів у діяльності, тим самим забезпечувалася база для нарощення інноваційного потенціалу компаній. 
Відомі різні підходи до оцінки інноваційного потенціалу компаній, які базуються на оцінці його структурних складових: кадровий, інформаційний, ринковий, науково-технічний, виробничий, фінансовий, організаційний i iнші потенціали. Дані методи відрізняються великим набором показників, що мають різну розмірність. Деякі вчені (Ф. Бунс, К. Монталво, Дж. Квіст, М. Вагнер) пропонують здійснювати бальну оцінку приватних показників, інші дотримуються статистичних, кількісних даних [8]. Втім, не всі фактори, які характеризують інноваційний потенціал компанії, здатні приєднатися до певного методу, тому використовується змішаний варіант оцінки інноваційного потенціалу. Яскравим поданням застосування експертної оцінки є метод, запропонований Г. Арсезе, С. Фламіні, М. К. Луккетті, О. Мартуччі, в основі якого лежить діагностика внутрішнього середовища компанії. Елементи, що піддаються аналізу, включають у себе продуктовий, функціональний, ресурсний та організаційний блоки, а також блок управління [9].

Інший погляд на оцінку інноваційного потенціалу запропонований А. Каммарано, М. Капуто, Е. Ламберті, Ф. Мікеліно [10]. Відповідно до цього підходу оцінка інноваційного потенціалу компаній грунтується на принципах: а) орієнтації на кінцеві результати; б) єдності критерію ефективності; в) комплексності оцінки; г) раціонального співвідношення окремих груп показників; д) розмежування ключових показників результативності і показників ефективності; ж) урегульованості кола показників.

Важливим внеском вказаних авторів в методику оцінки інноваційного потенціалу компаній є розроблена система показників опору, що відображають рівень сприйнятливості до інновацій [10]. При цьому інноваційний потенціал визначається на основі наукового i науково-технічного потенціалів та потенціалу сприйнятливості інновацій. Процедура оцінки інноваційного потенціалу проводиться диференційовано за кожною складовою інноваційного потенціалу, після чого визначається загальний інтегральний показник за формулою.

$$
\Pi_{\text {IП }}=\alpha \mathrm{O}_{\text {нп }}+\beta \mathrm{O}_{\text {нтп }}+\gamma \mathrm{O}_{\text {сі }}
$$

де $-\alpha, \beta, \gamma-$ коефіцієнти значущості узагальнених показників; $\mathrm{O}_{\text {нп }}$ - значення узагальненого показника наукового потенціалу; $\mathrm{O}_{\text {нтп }}$ значення узагальненого показника науково-технічного потенціалу; $\mathrm{O}_{\mathrm{ci}}-$ значення узагальненого показника сприйнятливості інновацій. 
Оцінка коефіцієнтів значущості здійснюється експертним шляхом. Отримані експертні оцінки проходять обробку за методом Дельфі, в результаті чого виявляються значення коефіцієнтів $\alpha, \beta, \gamma$. Недоліки даного методу, на наш погляд, полягають, по-перше, в досить вузькому поданні інноваційного потенціалу через підсистеми наукового i науково-технічного потенціалів та рівня сприйнятливості інновацій. Інноваційний потенціал компанії визначається великою кількістю груп показників, які оцінюють потенціали підсистем, таких як виробничий, трудовий, маркетинговий, ресурсний, інтелектуальний, науковотехнологічний, фінансово-економічний, інвестиційний та управлінський потенціали відповідно.

Рівень інноваційного потенціалу компанії залежить від умов, що виникають у результаті взаємодії всіх підсистем, що визначають загальний рівень розвитку і підготовленості компанії до інноваційних трансформацій, які можуть полягати як у виробництві інноваційної продукції, так і в підвищенні загального рівня інноваційного розвитку виробництва. По-друге, недоліком даного методу $\epsilon$ відсутність системного бачення про взаємозв'язки між елементами, структурою процесів і їх розгляду в динаміці. Метод передбачає деталізовану комплексну оцінку інноваційного потенціалу, проте комплексна оцінка - не означає системна оцінка.

Комплексність виражається в більшій деталізації і поглибленому аналізі показників за різними напрямками діяльності, в той час як системність визначається взаємозв'язками між елементами системи i результатами їх взаємодії, що характеризують якість і результат роботи системи (компанії) в цілому. Саме системність у взаємодії всіх складових компанії розкриває рівень іiі інноваційного потенціалу [11].

Метод оцінки інноваційного потенціалу, запропонований Ф. Бунс, Ф. Людеке-Фройнд дозволяє оцінити не тільки ресурси компанії, а й поточний стан виробництва [12]. Такий метод має багато позитивних характеристик, бо кінцеві результати достовірні завдяки розрахункам за конкретними формулами, для отримання цих результатів не потрібні фахівці з інших установ і такий метод дозволяє контролювати точність обраного напрямку інноваційного розвитку з позицій тимчасового i подальшого фінансового стану компанії. Проте цей метод не позбавлений недоліку, оскільки при його використанні можна розрахувати тільки один показник інноваційних можливостей компанії - забезпеченість фінансово-економічними ресурсами, тоді як інноваційний потенціал компанії включає в себе не тільки фінансову складову. 
Поряд 3 методами оцінки інноваційного потенціалу за підсистемами, існують методи оцінки інноваційного потенціалу компанії з позиції економічного аналізу [13]. В основі аналізу інноваційного потенціалу компанії лежить оцінка іiі фінансової стійкості. Завданням такого аналізу є визначення можливостей компанії для впровадження інновацій у виробничий процес за рахунок власних оборотних коштів; власних оборотних коштів i довгострокових кредитів; власних оборотних коштів, довгострокових i короткострокових кредитів. У процесі аналізу виявляється ступінь забезпеченості запасів і витрат власними і позиковими джерелами фінансування, при цьому фінансова стійкість залежить від співвідношення власних і позикових коштів.

За допомогою даного методу виявляються надлишки або недоліки у формуванні фінансових ресурсів, у результаті чого стає очевидним, чи зможе компанія здійснити покриття виробничих витрат за умови впровадження інновацій. Метод передбачає застосування односторонньої оцінки інноваційного потенціалу компанії і при цьому не враховується вплив інших його підсистем, крім фінансовоекономічної підсистеми.

Значимість даного методу полягає в обгрунтуванні необхідності фінансової стійкості компанії, зокрема і стійкості економічної системи в цілому для забезпечення можливостей інноваційного розвитку компанії і нарощення іiі інноваційного потенціалу.

Застосування методу, запропонованого Д. С. Ремер і А. П. Ньєто, дозволяє оцінити стан компанії за цілою низкою критеріїв, які розкривають іiі інноваційний потенціал. Для кожного бізнес-етапу вибираються певні характеристики, яким присвоюються рейтингові оцінки. Для цих характеристик формуються критерії оцінки діяльності компанії, що використовуються експертом як умовний норматив розвитку цього етапу [14]. За кожною 3 характеристик механічно обчислюється інтегральна оцінка як середня оцінка по всіх етапах. Інтегральна оцінка інноваційному потенціалу компанії в цілому дається як підсумкова таблиця, в якій наведено оцінки за кожним з розглянутих етапів.

Відповідно до запропонованого методу С. Шальтегер, Ф. Л. Фройнд, Е. Г. Гансен, для отримання інтегральної оцінки інноваційного потенціалу компанії оцінюється кожний його елемент: фінансовий, виробничо-технологічний, кадровий, споживчий, організаційний, маркетинговий, науково-технічний, інформаційний та управлінський потенціали, а також інноваційна культура [15]. Цей метод передбачає 
використання системи індикаторів, що включає в себе цілу низку коефіцієнтів, які характеризують кожний елемент інноваційного потенціалу компанії.

Дослідженням встановлено, що багато методів не враховують критерій системності, відсутня наочність представлення результатів, що зараджує сприйняттю інформації, а також не здійснюється оцінка динаміки розвитку системи. Не всі розглянуті методи передбачають визначення стану стійкості компанії, як основи для формування іiі інноваційного потенціалу. На основі порівняльного аналізу наведених методів можна констатувати, що проблемним місцем у нарощенні інноваційного потенціалу компанії $\epsilon$ визначення взаємозв'язків i взаємовпливу між виробничими процесами, без яких неможливо системне уявлення про роботу компанії. Сукупність цих недоліків визначає передумови для пошуку нових методів діагностики / аналізу i розробки методичного забезпечення, яке компенсує існуючі недоліки в оцінці інноваційного потенціалу компаній.

Зважаючи на перераховані вище недоліки, виникла необхідність у розробці методу, що дозволяє комплексно оцінити інноваційний потенціал компаніі. Такий метод був розроблений Е. Фон Гіппель [16]. В основі методу покладено аналіз економічного змісту інноваційного потенціалу. Виходячи з цього, система індикаторів відповідає сутності інноваційного потенціалу. В системі виділені групи індикаторів, кожна 3 яких найбільш повно характеризує компоненти інноваційного потенціалу. Під інноваційним потенціалом Е. Фон Гіппель розуміє можливість, готовність і здатність компанії як системи створювати при наявному ресурсному забезпеченні та використовувати інновації для отримання різних видів ефекту [17]. Досліджуючи сутність інноваційного потенціалу компанії, Е. Фон Гіппель виділяє два рівня:

1) характеризує наявність ресурсів у компанії, необхідних для інноваційної діяльності (фінансовий, науково-технічний, кадровий, виробничо-технологічний, організаційно-управлінський потенціали);

2) характеризує фактори інноваційної активності компанії (можливість, готовність, здатність, бажання компанії до впровадження інновацій). Е. Фон Гіппель виділив цілу низку факторів, за якими здійснюється діагностика й оцінка інноваційного потенціалу.

Відбір факторів здійснюється на основі комплексного аналізу / діагностики. В результаті в число приватних факторів включені різні характеристики, необхідність врахування яких пояснюється, по-перше, їх впливом на інноваційний потенціал компанії, по-друге, ступенем їх керованості. 3 урахуванням запропонованої структури інноваційного 
потенціалу, індикатори оцінки об'єднані в шість груп, що характеризують кадровий, фінансовий, науково-технічний, виробничотехнологічний, організаційно-управлінський потенціали і інноваційну активність компанії.

Таким чином, всебічний аналіз залежності елементів інноваційного потенціалу від приватних факторів дозволив виділити індикатори, що характеризують можливість, здатність, готовність і бажання компанії до інноваційної діяльності по кожній з груп (табл. 1).

Таблиця 1 - Система індикаторів оцінки інноваційного потенціалу компаній

\begin{tabular}{|c|c|c|}
\hline Показник & Формула розрахунку & Характеристика показника \\
\hline \multicolumn{3}{|c|}{ Кадровий потенціал } \\
\hline $\begin{array}{l}\text { Частка працівників, } \\
\text { зайнятих } \\
\text { дослідженнями i } \\
\text { розробками }\left(\Pi_{1}\right)\end{array}$ & $\Pi_{1}=\frac{\mathrm{Ч}_{\text {НдДКР }}}{\mathrm{Ч}_{\text {заг. }}} \times 100$ & $\begin{array}{l}\mathrm{Ч}_{\text {заг. }}-\text { загальна чисельність } \\
\text { працівників підприємства, чол.; } \\
\mathrm{Ч}_{\text {Нддкр }-}-\text { чисельність } \\
\text { працівників, зайнятих у сфері } \\
\text { НДДКР, чол. }\end{array}$ \\
\hline $\begin{array}{lr}\text { Рівень } & \text { освіти } \\
\text { менеджерів } & \text { вищої і } \\
\text { середньої ланки }\left(\Pi_{2}\right)\end{array}$ & $\Pi_{2}=\frac{\mathrm{P}_{\text {освіта }}}{\mathrm{P}_{\text {заг. }}} \times 100$ & $\begin{array}{l}\mathrm{P}_{\text {освіта. }} \text { - кількість керівників і } \\
\text { фахівців, які мають вищу } \\
\text { освіту, чол.; Р заг. - загальна } \\
\text { кількість керівників і фахівців, } \\
\text { чол. }\end{array}$ \\
\hline $\begin{array}{lr}\text { Частка } & \text { працівників, } \\
\text { які } & \text { пройшли } \\
\text { навчання }\left(\Pi_{3}\right)\end{array}$ & $\Pi_{3}=\frac{\mathrm{K}_{\text {навчання }}}{\mathrm{Ч}_{\text {заг. }}} \times 100$ & $\begin{array}{l}\text { К Кавчання. - кількість персоналу, } \\
\text { які пройшли навчання / } \\
\text { підвищили кваліфікацію в } \\
\text { звітному періоді, чол. }\end{array}$ \\
\hline $\begin{array}{l}\text { Частка витрат на } \\
\text { навчання } \\
\left(\Pi_{4}\right)\end{array}$ & $\Pi_{4}=\frac{\mathrm{B}_{\text {навчання }}}{\mathrm{B}_{\text {технолог.ін. }}} \times 100$ & $\begin{array}{l}\mathrm{B}_{\text {навчання. }}-\text { витрати на навчання } \mathrm{i} \\
\text { підготовку персоналу, тис грн; } \\
\text { В }_{\text {технолог.ін. }}-\text { загальні витрати на } \\
\text { технологічні інновації, тис грн }\end{array}$ \\
\hline \multicolumn{3}{|c|}{ Фінансовий потенціал } \\
\hline $\begin{array}{l}\text { Наявність власного } \\
\text { капіталу }\left(\Pi_{5}\right)\end{array}$ & $\Pi_{5}=\mathrm{BK}$ & $\begin{array}{lcc}\text { ВК } & - & \text { власний } \\
\text { підприємства, тис грн } & \text { капітал } \\
\end{array}$ \\
\hline $\begin{array}{l}\text { Частка витрат } \\
\text { технологічні } \\
\text { інновації }\left(\Pi_{6}\right)\end{array}$ & $\Pi_{6}=\frac{B_{\text {технолог.ін. }}}{0_{\text {заг. }}} \times 100$ & $\begin{array}{l}\mathrm{O}_{\text {заг }}-\text { загальний } \\
\text { відвантажених обсяг } \\
\text { виконаних робіт і послуг за } \\
\text { звітний період, тис грн }\end{array}$ \\
\hline
\end{tabular}


Продовження таблиці 1

\begin{tabular}{|c|c|c|}
\hline \multicolumn{3}{|c|}{ Науково-технічний потенціал } \\
\hline $\begin{array}{l}\text { Забезпеченість } \\
\text { інтелектуальною } \\
\text { власністю }\left(\Pi_{7}\right)\end{array}$ & $\Pi_{7}=\frac{\mathrm{B}_{\text {немат.активи }}}{\mathrm{B}_{\text {необоротні активи }}} \times 100$ & $\begin{array}{l}\text { В немат.активи }_{\text {нематеріальних }}-\text { активів, тиртість } \\
\text { грн; } \\
\text { В необоротні.активи }- \text { необоротні } \\
\text { активи, тис грн }\end{array}$ \\
\hline $\begin{array}{l}\text { Результативність } \\
\text { освоєння інновацій } \\
\left(\prod_{8}\right)\end{array}$ & $\Pi_{8}=\frac{\mathrm{Ч}_{\text {впровадж.нов. }}}{\mathrm{Ч}_{\text {розроблен.нов. }}} \times 100$ & $\begin{array}{l}\mathrm{Ч}_{\text {впровадж.нов. }} \text { i } \mathrm{\Psi}_{\text {розроблен.нов. }}-\text { число } \\
\text { впроваджених і розроблених } \\
\text { нововведень за } \\
\text { аналізований } \\
\text { відповідно, од. відповідно }\end{array}$ \\
\hline $\begin{array}{lr}\text { Частка витрат } & \text { на } \\
\text { дослідження } & \mathrm{i} \\
\text { розробки }\left(\Pi_{9}\right) & \end{array}$ & $\Pi_{9}=\frac{\mathrm{B}_{\text {дослідж.і розроб. }}}{\mathrm{B}_{\text {технолог.ін. }}} \times 100$ & $\begin{array}{llr}\text { дослідж.і розроб. }_{\text {д }} \text { витрати на } \\
\text { дослідження i розробки } \\
\text { звітному періоді, тис грн }\end{array}$ \\
\hline \multicolumn{3}{|c|}{ Виробничо-технологічний потенціал } \\
\hline $\begin{array}{l}\text { Наявність основних } \\
\text { засобів }\left(\prod_{10}\right)\end{array}$ & $\Pi_{10}=03$ & $\begin{array}{lccc}\text { O3 } & - & \text { основні } & \text { засоби } \\
\text { підприємства, тис грн } & \end{array}$ \\
\hline $\begin{array}{l}\text { Освоєння } \\
\text { техніки }\left(\Pi_{11}\right)\end{array}$ & $\Pi_{11}=\frac{0 \Phi_{\text {нов. }}}{0 \Phi_{\text {середньорічна }}} \times 100$ & $\begin{array}{l}\text { ОФ }{ }_{\text {нов. }}-\text { вартість нововведених } \\
\text { основних виробничих фондів } \\
(\text { ОВФ), тис грн; ОФ } \\
\text { середньньорічна. } \\
\text { тис грн }\end{array}$ \\
\hline $\begin{array}{ll}\text { Освоєння } & \text { нової } \\
\text { продукції }\left(\Pi_{12}\right) & \end{array}$ & $\Pi_{12}=\frac{0_{\text {iн. }}}{0_{\text {заг. }}} \times 100$ & \begin{tabular}{ll}
$\mathrm{O}_{\text {ін. }}-$ обсяг & \multicolumn{1}{c}{ відвантаженої } \\
інноваційної & продукції \\
звітний період, тис грн
\end{tabular} \\
\hline $\begin{array}{l}\text { Частка витрат на } \\
\text { придбання машин і } \\
\text { обладнання }\left(\Pi_{13}\right)\end{array}$ & $\Pi_{13}=\frac{B_{\text {маш.і облад. }}}{B_{\text {технол. }}} \times 100$ & $\begin{array}{l}\mathrm{B}_{\text {технол. }}-\text { витрати на придбання } \\
\text { технологій у звітному періоді, } \\
\text { тис грн; } \mathrm{B}_{\text {маш.і облад. }}-\text { витрати на } \\
\text { придбання машин і обладнання } \\
\text { в звітному періоді, тис грн }\end{array}$ \\
\hline $\begin{array}{l}\text { Частка витрат на } \\
\text { придбання } \\
\text { технологій }\left(\Pi_{14}\right)\end{array}$ & $\Pi_{14}=\frac{\mathrm{B}_{\text {технол. }}}{\mathrm{B}_{\text {технолог.ін. }}} \times 100$ & \\
\hline \multicolumn{3}{|c|}{ Організаційно-управлінський потенціал } \\
\hline $\begin{array}{l}\text { Масштаб компанії } \\
\left(\Pi_{15}\right)\end{array}$ & $\Pi_{15}=\mathrm{U}_{\text {заг. }}$ & \\
\hline $\begin{array}{l}\text { Галузева } \\
\text { приналежність } \\
\text { компанії }\left(\Pi_{16}\right)\end{array}$ & & \\
\hline
\end{tabular}


Продовження таблийі 1

\begin{tabular}{|c|c|c|}
\hline $\begin{array}{l}\text { Відповідність } \\
\text { організаційних } \\
\text { структур і } \\
\text { управлінських систем } \\
\text { компанії завданням } \\
\text { інноваційного } \\
\text { процесу }\left(\Pi_{17}\right)\end{array}$ & $\Pi_{17}=\frac{M_{\text {середне }}{ }^{123}}{M_{\text {ідеальне }}{ }^{123}} \times 100$ & $\begin{array}{lrr}\mathrm{M}_{\text {середне }} 123 & - & \text { середнє } \\
\text { арифметичне } & \text { суми } & \text { балів } \\
\text { анкети; } & \mathrm{M}_{\text {ідеальне }} & - \\
\text { максимально } & \text { можливий } & \text { бал за } \\
\text { анкетою } & & \end{array}$ \\
\hline $\begin{array}{l}\text { Наявність системи } \\
\text { мотивації } \\
\text { інноваційної } \\
\text { (творчої) активності } \\
\text { персоналу }\left(\Pi_{18}\right)\end{array}$ & $\Pi_{18}=\frac{M_{\text {середне }^{2}}}{M_{\text {ідеальне }}{ }^{2}} \times 100$ & \\
\hline \multicolumn{3}{|c|}{ Фактори інноваційної активності } \\
\hline $\begin{array}{l}\text { Фактори інноваційної } \\
\text { активності }\left(\Pi_{19}\right)\end{array}$ & $\Pi_{19}=\frac{M_{\text {середне }^{2}}}{M_{\text {ідеальне }}{ }^{2}} \times 100$ & \\
\hline
\end{tabular}

Джерело: складено за [16-17].

Розроблена Е. Фон Гіппель система показників оцінки інноваційного потенціалу компаній володіє деякими властивостями:

a) обчислення показників здійснюється в рамках кадрового, фінансового, науково-технічного, виробничо-технологічного та організаційно-управлінського потенціалів і змоги та бажання компанії до впровадження інновацій. Такий метод до оцінки інноваційного потенціалу компанії, що спирається на системний підхід, дозволяє 3 різних сторін не тільки робити діагностику й оцінку впливу факторів на інноваційний потенціал компанії, але і виявити ключові причини, що кардинально впливають на стан системи (компанії) в цілому;

б) метод передбачає використання відносно невеликої кількості показників, що спрощує розрахунки, але при цьому забезпечує досить повне охоплення елементів інноваційного потенціалу компанії;

в) поряд зі уніфікованими статистичними показниками в методі використовуються скомбіновані на їх основі розрахункові дані;

г) використовується мінімальна частка експертних бальних оцінок у загальному складі показників і не передбачено застосування вагових коефіцієнтів значущості, що дозволяє уникнути суб'єктивність отриманого результату;

д) результат застосування даного підходу не лише дає інтегральну оцінку інноваційного потенціалу компанії, а й дозволяє виявити конкретні елементи, які потребують управлінського впливу для підвищення загального рівня інноваційного потенціалу.

Цікавим, на наш погляд, є метод оцінки інноваційного потенціалу компанії, запропонований М. Гримальді, Л. Крічеллі, Ф. Рого [18]. 
Вчені вважають доцільним оцінювати інноваційний потенціал як характеристику компанії, яка відображає такі визначальні елементи: а) науковий потенціал або забезпеченість компанії висококваліфікованими фахівцями i науковими кадрами; б) сприйнятливість компанії до інновацій (інноваційність) чи можливість реалізації нововведень у виробничому процесі; в) ринковий потенціал.

Реалізації даного підходу передбачає виокремлення двох складових інноваційного процесу в компанії - процес освоєння новації у виробництві (спромога створити інновацію) і процес створення новації (змога використати нововведення), а тому розділяють дефініції «науковий потенціал компанії» i «інноваційна сприйнятливість компанії» (інноваційність) як складові частини дефініції «інноваційний потенціал».

Науковий потенціал компанії можна визначити як здатність компанії створювати власні інноваційні рішення. Звідси випливає, що науковий потенціал - це, насамперед, трудові ресурси компанії, які можна оцінити 3 позиції можливості генерації власних інноваційних рішень у сфері технології, продукту, послуги, управління чи проведення відомих «не інноваційних» трансформацій за допомогою інноваційних рішень.

Інноваційна сприйнятливість (інноваційність) $\epsilon$ складовою частиною інноваційного потенціалу, що відображає здібність компанії пристосовувати нововведення і $€$ необхідною, але не достатньою характеристикою компанії, що здійснює інноваційний процес.

Інноваційність залежить від різних зовнішніх $\mathrm{i}$ внутрішніх факторів. До внутрішніх факторів відносимо наявність у компанії зручних психологічних, кадрових, фінансових, організаційних i технічних умов для впровадження інновацій. Важливим фактором у підтримці інноваційних починань у компанії вважаємо інформаційний контекст, тобто яке місце відводиться інформації про нововведення в системі прийняття управлінських рішень. Вагому роль відіграють зовнішні фактори, пов'язані з розвитком ринкових відносин, станом фінансово-економічної системи, соціально-економічним і політичним станом у країні, розвиненістю інфраструктури розміщення компанії, наявністю / відсутністю зручного інноваційного клімату та підтримки зі сторони державних органів.

Поряд 3 науковим потенціалом та інноваційністю виділяємо ще таку складову інноваційного потенціалу як ринковий потенціал, що відображає затребуваність новації на ринку, масштаб реалізації нововведення. Для належної оцінки інноваційного потенціалу компанії розглянемо систему індикаторів, необхідних для діагностики й оцінки його структурних складових (табл. 2). 
Таблиця 2 - Система індикаторів оцінки структурних складових інноваційного потенціалу компанії

\begin{tabular}{|c|c|c|}
\hline Індикатор & Формула розрахунку & Характеристика показника \\
\hline \multicolumn{3}{|c|}{ Науковий потенціал } \\
\hline $\begin{array}{l}\text { Коефіцієнт } \\
\text { наукових } \\
\text { досліджень }\left(\mathrm{K}_{\text {нд }}\right)\end{array}$ & $\mathrm{K}_{\text {нд }}=\frac{\mathrm{B}_{\mathrm{H.}}}{\mathrm{A}} \times 100$ & 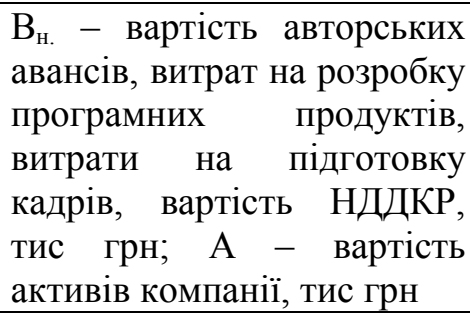 \\
\hline $\begin{array}{l}\text { Коефіцієнт } \\
\text { персоналу, } \\
\text { зайнятого НДДКР } \\
\text { (К Керсонал })\end{array}$ & $\mathrm{K}_{\text {персонал }}=\frac{\Pi_{\text {НдДКР }}}{\mathrm{Ч}_{\text {сер. }}} \times 100$ & 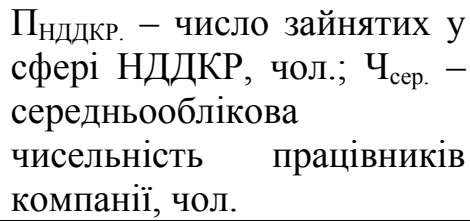 \\
\hline $\begin{array}{l}\text { Коефіцієнт } \\
\text { освіченості } \\
\text { персоналу }\left(\mathrm{K}_{\text {освіти }}\right)\end{array}$ & $\mathrm{K}_{\text {освіти }}=\frac{\mathrm{Ч}_{\text {вища освіта }}}{\mathrm{Ч}_{\text {сер. }}} \times 100$ & $\begin{array}{l}\mathrm{Ч}_{\text {вища освіта }}-\text { чисельність } \\
\text { працівників } \\
\text { освітою, чол. }\end{array}$ \\
\hline \multicolumn{3}{|c|}{ Інноваційна сприйнятливість } \\
\hline $\begin{array}{l}\text { Коефіцієнт } \\
\text { забезпеченості } \\
\text { інтелектуальною } \\
\text { власністю } \\
\left(\mathrm{K}_{\text {інт.власність }}\right) \\
\end{array}$ & $\mathrm{K}_{\text {інт.власність }}=\frac{\mathrm{B}_{\text {інтелектуальна }}}{\mathrm{A}_{\text {необоротні активи }}} \times 100$ & $\begin{array}{l}\mathrm{B}_{\text {iнтелектуальна }} \\
\text { інтелектуальна } \\
\text { тис грн; } \\
\mathrm{A}_{\text {необоротні активи }}-\text { необосність, } \\
\text { активи, тис грн }\end{array}$ \\
\hline $\begin{array}{l}\text { Коефіцієнт } \\
\text { оновлення } \\
\text { обладнання } \\
\text { (К оновл.облад.) }\end{array}$ & $\mathrm{K}_{\text {оновл.облад. }}=\frac{0 \Phi_{\text {нов. }}}{0 \Phi_{\text {середньорічна }}} \times 100$ & 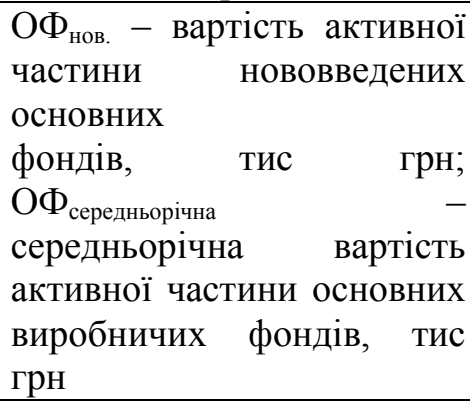 \\
\hline \multicolumn{3}{|c|}{ Ринковий потенціал } \\
\hline $\begin{array}{l}\text { Коефіцієнт } \\
\text { впровадження } \quad \text { у } \\
\text { виробництво нової } \\
\text { продукції } \\
\left(K_{\text {впровадж.нов.прод. })}\right.\end{array}$ & $\mathrm{K}_{\text {впровадж.нов.прод. }}=\frac{V_{\text {вир.інн.прод. }}}{V_{\text {вир.прод. }}} \times 100$ & $\begin{array}{lrr}\mathrm{V}_{\text {вир.інн.прод }} & - & \text { обсяг } \\
\text { виробництва } & \text { інноваційної } \\
\text { продукції; } & \\
\mathrm{V}_{\text {вир.прод. }} & - & \text { обсяг } \\
\text { виробництва } & \text { продукції } \\
\text { компанії } & & \end{array}$ \\
\hline $\begin{array}{l}\text { Коефіцієнт } \\
\text { інтенсивності } \\
\text { інноваційних } \\
\text { витрат }\left(К_{\text {iнтенс.витрат }}\right) \\
\end{array}$ & $\mathrm{K}_{\text {інтенс.витрат }}=\frac{\mathrm{B}_{\text {iнн. }}}{\text { ДВ }} \times 100$ & $\begin{array}{l}\mathrm{B}_{\text {нн. }}-\text { витрати на інновації, } \\
\text { тис грн; } \\
\text { ДВ - додана вартість, тис } \\
\text { грн }\end{array}$ \\
\hline
\end{tabular}

Джерело: складено за [16-17].

Частина перерахованих коефіцієнтів і способів їх розрахунку запропоновані зарубіжними вченими [18-20]. Вже згадана система показників розраховується за даними бухгалтерського обліку і даними кадрового складу компанії. Для можливості інтегрованої оцінки інноваційного потенціалу компанії визначається середня величина 
показників значень коефіцієнтів у кожній групі: групі показників, що характеризують науковий потенціал, інноваційність та ринковий потенціал відповідно.

В даному випадку в зв'язку з малим обсягом порівнювальних показників у групах доцільно використовувати середне арифметичне по групі, яке розраховується за формулою.

$$
\mathrm{X}=\frac{\mathrm{X}_{1}+\mathrm{X}_{2}+\mathrm{X}_{3}+\cdots+n}{n}
$$

Сума значень коефіцієнтів групи ділиться на число коефіцієнтів у групі. Причому передбачається, що кожен з критеріїв i, відповідно запропонованих показників мають однакову вагу. У зв'язку з цим при визначенні інтегральних показників вагові коефіцієнти по кожному показнику будуть рівні 1.

Зазначимо, що форми середньої величини утворені від єдиної статечної середньої і відрізняються одна від одної лише показниками ступеня. Точність розрахунку середньої величини можна перевірити за допомогою правила мажорантості, згідно з яким чим вище ступінь форми середньої величини, що розраховується, тим більше значення середньої. В даному випадку правило виконується.

Середнє арифметичне по групі коефіцієнтів, що характеризують науковий потенціал, визначається за формулою.

$$
K_{1}=\frac{K_{\text {нд }}+K_{\text {персонал }}+K_{\text {освіти }}}{3}
$$

Середнє арифметичне по групі коефіцієнтів, що характеризують інноваційність, розраховується за формулою.

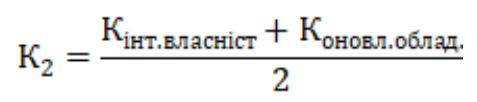

Середнє арифметичне по групі коефіцієнтів, що характеризують ринковий потенціал, розраховується за формулою.

$$
\kappa_{3}=\frac{K_{\text {впроваджнов, прод. }}+K_{\text {iнтенс.витрат }}}{2}
$$

Визначимо також інтегральний показник інноваційного потенціалу високотехнологічної компанії за формулою.

$$
\kappa_{\text {інтегральний }}=\frac{\kappa_{1}+K_{2}+K_{3}}{3}
$$


Оцінку інноваційного потенціалу компанії доцільно вести у вигляді порівняння отриманих значень коефіцієнтів до встановлених граничних величин. В якості критеріїв для розрахунку порогових значень коефіцієнтів можна використовувати дані статистичного обстеження інноваційної діяльності провідних промислових компаній, а також результати застосування експертних методів. Оцінка рівня кожного показника проводиться шляхом віднесення його до певної групи з використанням вербально-числової шкали Гаррінгтона [21].

Відомі граничні значення інтегральних величин показників для групи коефіцієнтів, що характеризують науковий потенціал, інноваційність і ринковий потенціал $\left(\mathrm{K}_{1}, \mathrm{~K}_{2}, \mathrm{~K}_{3}\right)$, дозволили визначити інтервали їх порогових значень (табл. 3).

Таблиця 3 - Розподіл інтервалів значень, що характеризують рівень інноваційного потенціалу

\begin{tabular}{|c|c|c|c|c|c|}
\hline \multirow{2}{*}{$\begin{array}{c}\text { Інтегральний показник за групою } \\
\text { коефіцієнтів, що характеризують } \\
\text { науковий потенціал, } \\
\text { інноваційність та ринковий } \\
\text { потенціал }\end{array}$} & \multicolumn{5}{|c|}{ Граничне значення рівня інноваційного потенціалу } \\
\hline & $\begin{array}{c}\text { Дуже } \\
\text { високий } \\
(0,8 \ldots 1)\end{array}$ & $\begin{array}{l}\text { Високий } \\
(0,6 \ldots 0,8)\end{array}$ & $\begin{array}{l}\text { середній } \\
(0,4 \ldots 0,6)\end{array}$ & $\begin{array}{c}\text { низький } \\
(0,2 \ldots 0,4)\end{array}$ & $\begin{array}{c}\text { дуже } \\
\text { низький } \\
(0 \ldots . .0,2)\end{array}$ \\
\hline $\mathrm{K}_{1}=\frac{\mathrm{K}_{\mathrm{Hд}}+\mathrm{K}_{\text {персонал }}+\mathrm{K}_{\text {освіти }}}{3}$ & $>0,16$ & 0,14 & 0,11 & 0,06 & $<0,06$ \\
\hline $\mathrm{K}_{2}=\frac{\mathrm{K}_{\text {інт.власніст }}+\mathrm{K}_{\text {оновл, облад. }}}{2}$ & $>0,3$ & 0,22 & 0,15 & 0,07 & $<0,07$ \\
\hline $\mathrm{K}_{3}=\frac{\mathrm{K}_{\text {впроваджнов,прод, }}+\mathrm{K}_{\text {інтенс.витрат }}}{2}$ & $>0,29$ & 0,24 & 0,13 & 0,06 & $<0,06$ \\
\hline $\mathrm{K}_{\text {інтегральний }}=\frac{\mathrm{K}_{1}+\mathrm{K}_{2}+\mathrm{K}_{3}}{3}$ & $>0,25$ & 0,2 & 0,15 & 0,10 & $<0,10$ \\
\hline
\end{tabular}

В даному випадку необхідно провести нормування запропонованих показників. Для приведення всіх приватних показників до порівнянного вигляду були стандартизовані їх значення шляхом застосування коефіцієнтів нормування $\mathrm{K}_{\mathrm{n}}$ або надання відповідного бального значення у відповідності до розробленого комплексу критеріальних значень для системи показників.

Запропоновані межі показників спираються на зарубіжні наукові праці в сфері інноваційної діяльності, а також на дані статистичної звітності [18-20]. Згідно досліджуваного методу, отримані відносні коефіцієнти $\mathrm{K}_{\mathrm{n}}$ знаходяться в межах від 0 до 10. Інтегральним значенням рівня інноваційного потенціалу компанії буде крива, утворена шляхом нанесення значень коефіцієнтів $\mathrm{K}_{\mathrm{n}}$ на рисунок.

Рисунок демонструє рівень інноваційного потенціалу за кожним компонентом, що дозволяє розробити заходи впливу на конкретні складові для підвищення загального рівня інноваційного потенціалу компанії. При побудові рисунка на горизонтальній осі необхідно 
відзначити показники оцінки, на вертикальній осі - значення від 0 до 10. Значенню низького рівня інноваційного потенціалу компанії відповідатимуть показники, що потрапляють у відрізок від 0 до 3 , середнього - від 3 до 7, високого - від 7 до 10 відповідно.

Для виявлення трендів i перспектив розвитку інноваційного потенціалу компанії доцільно проводити оцінку зазначених показників в динаміці.

Таким чином, описані методи дозволять удосконалити процедуру оцінки інноваційного потенціалу компаній, виявити можливості для підвищення його рівня, а також розробити i проаналізувати альтернативні варіанти подальшого стратегічного розвитку компаній.

Висновки. Теоретично обгрунтовано економічний зміст структурних елементів інноваційного потенціалу компанії, який $\epsilon$ складною системою взаємозв'язків і взаємодії кадрового, наукового, маркетингового, екологічного, фінансово-інвестиційного та організаційно-технічного потенціалів тощо 3 урахуванням впливу факторів зовнішнього і внутрішнього середовищ.

Удосконалено методичний підхід до формування інструментарію оцінки стану інноваційного потенціалу компаній, що базується на розрахунку показників, що діагностують його інтегральний рівень i ефективність використання окремих видів ресурсів, що дає можливість забезпечити комплексну інформаційну підтримку процесів регуляції інноваційної сфери компаній.

Запропоновано методичний підхід до інтегральної оцінки рівня інноваційного потенціалу компаній, який побудований з урахуванням функціональної залежності виділених структурних елементів інноваційного потенціалу. Обгрунтовано необхідність інтерпретації отриманого значення інтегрального показника інноваційного потенціалу за рівнями відповідно до шкали, удосконаленої автором, 3 використанням вербально-числової шкали Гаррінгтона.

Перспективи подальших наукових розробок пов'язані нагальною необхідністю наукового аналізу й узагальнення кращого міжнародного досвіду в сфері інтегральної оцінки рівня інноваційного потенціалу компаній.

Практична цінність результатів статті полягає в тому, що запропонований метод комплексної оцінки інноваційного потенціалу компаній здатний забезпечити визначення його рівня 3 високими показниками точності та об'єктивності, що в кінцевому випадку дозволяє виявити проблемні елементи у складі кожного компонента інноваційного потенціалу та виробити рекомендації щодо підвищення рівня інноваційного потенціалу за певними його компонентами.

Розроблений метод та методичні рекомендації можуть бути використані при розробці управлінських рішень для підвищення рівня 


\section{інноваційного потенціалу компаній.}

\section{Література:}

1. Антикайнен М., Мякіпя М., Ахонен М. Мотивація та підтримка співпраці у відкритих інноваціях. Свропейський журнал управління інноваціями. 2010. №13(1), C. 100-119. https://doi.org/10.1108/14601061011013258.

2. Енкель Е., Гассманн О., Чесбро Х. Відкриті НДДКР та відкриті інновації: вивчення феномену. Управління науково-дослідними роботами. 2009. №39(4), С. 311-316. https://doi.org/10.1111/j.1467-9310.2009.00570.x.

3. Хелфат Е., Куінн Дж. Б. Відкриті інновації: новий імператив для створення та отримання прибутку від технологій. Академія перспектив управління. 2006. №20(2), C. 86-88. https://doi.org/10.5465/amp.2006.20591014.

4. Чесброу Х. В. Ера відкритих інновацій. Огляд управління MIT Sloan. 2003. №44(3), C. 35-41.

5. Швердтнер В., Зіберт Р., Буссе М., Фрайзінгер У. Регіональна дорожня карта відкритих інновацій: нова основа для інноваційного регіонального розвитку. 2015. Стійкість. №7, С. 2301-2321. DOI: 10.3390/su7032301.

6. Мікеліно Ф., Каммарано А., Ламберті Е., Капуто М. Галузі знань, технологічні стратегії і відкриті інновації. Журнал управління технологіями та інноваціями. 2015. №10(2), C. 50-78. DOI: 10.4067/S0718-27242015000200005.

7. Вест Дж., Солтер А., Ванхавербеке В., Чесбро Х. Відкриті інновації: наступне десятиліття. Досліднищька політика. 2014. №43(5), С. 805-811. DOI: 10.1016/j.respol.2014.03.001.

8. Бунс Ф. Монтальво К. Квіст Й. Вагнер М. Сталі інновації, бізнес-моделі та економічні показники: огляд. Журнал чистого виробництвва. 2013. №45, С. 1-8. DOI: 10.1016/j.jclepro.2012.08.013.

9. Арсезе Г., Фламіні С., Луккетті М. С., Мартуччі О. Відкриті інновації в галузі сталого розвитку у харчовій галузі. Конференція: IV Форум світового форуму 3 питань сталого розвитку. 2014. №7, C. 8067-8090. DOI: 10.3390/wsf-4-g001.

10. Каммарано А., Капуто М., Ламберті Е., Мікеліно Ф. Стратегії співпраці у галузі досліджень та розробок для інновацій: емпіричне дослідження за допомогою аналізу соціальних мереж. Міжнародний журнал інновацій та управління технологіями. 2016. №14(1), 1740001. https://doi.org/10.1142/S0219877017400016.

11. Андрос С. В., Чан Сi Цо. Діджіталізація та підприємства: нові тренди інноваційного розвитку. Економічний журнал Одеського політехнічного університету. 2019. №4(10). C. 5-13. DOI: 10.5281/zenodo.3757950. ULR: https://economics.opu.ua/410-2_print.

12. Бунс Ф., Людеке-Фройнд Ф. Бізнес-моделі для стійких інновацій: стан техніки та кроки до порядку денного досліджень. Журнал чистого виробництва. 2012. №45, С. 9-19 (Спеціальний випуск Стійкі інновації та бізнес-моделі). ULR : https://ssrn.com/abstract=2103495.

13. Шемманн Б., Херрманн А. М., Чаппін М. М. Х., Хеймерікс Г. Дж. Ідеї краудсорсингу: залучення звичайних користувачів в фазу створення нових продуктів. Політика досліджень. 2016. №45(6), С. 1145-1154. DOI: 10.1016/j.respol.2016.02.003.

14. Ремер Д. С., Нієто А. П. Збірник та порівняння 25 методів оцінки проектів. Частина 1: Методи чистої теперішньої вартості та норми прибутку, Міжнародний журнал економіки виробництва. 1995. №42(1), С. 79-96. doi:10.1016/0925-5273(95)00104-2. 
15. Шалтеггер С., Фройнд Ф. Л., Хансен Е. Г. Бізнес-випадки для стійкості: роль інновацій бізнес-моделі для корпоративної сталості. Міжнародний журнал інноващій та сталого розвитку. 2012. №6(2), С. 95-119. DOI: 10.1504/IJISD.2012.046944.

16. Фон Гіппель Е. Демократизація інновацій: розвивається феномен інновацій користувачів. Журнал ділового адміністрування. 2005. №55, С. 63-78.

17. Фон Гіппель Е. Відкрита інновація для користувачів. Довідник з економіки інновачій. 2010. №1, С. 411-427.

18. Гримальді М., Крічеллі Л., Рого Ф. Методологія оцінки створення вартості в інноваційних спільнотах. Журнал інтелектуального капіталу. 2012. №13(3), С. 305-330. DOI: 10.1108/14691931211248882.

19. Чо К., Лі С. Як фірми можуть отримати ідеї від користувачів щодо стійких бізнес-інновацій, сталого розвитку, MDPI, Журнал відкритого доступу. 2015. №7(12), C. 1-21. 16039-16059. https://doi.org/10.3390/su71215802.

20. Бельдербос Р., Каррі М., Локшин Б. Спільні НДДКР і ефективність фірм. Політика досліджень. 2004. №33(10), С. 1477-1492. DOI: 10.1016/j.respol.2004.07.003.

21. Гаррінгтон Е. С. Функція бажаності. Промисловий контроль якості. 1965. № 21, C. 494-498.

\section{References:}

1. Antikainen, M., Mäkipää. M., Ahonen, M. (2010). Motivating and Supporting Collaboration in Open Innovation. European Journal of Innovation Management, Vol. 13, No. 1, pp. 100-119. https://doi.org/10.1108/14601061011013258.

2. Enkel, E., Gassmann, O., Chesbrough, H. (2009). Open R\&D and Open Innovation: Exploring the Phenomenon. R\&D Management, Vol. 39, Issue 4, pp. 311-316. https://doi.org/10.1111/j.1467-9310.2009.00570.x.

3. Helfat, E., Quinn, J. B. (2006). Open Innovation: The New Imperative for Creating and Profiting from Technology. Academy of Management Perspectives, Vol. 20, No. 2, pp. 86-88. https://doi.org/10.5465/amp.2006.20591014.

4. Chesbrough, H. W. (2003). The Era of Open Innovation. MIT Sloan Management Review, Vol. 44, No. 3, pp. 35-41.

5. Schwerdtner, W., Siebert, R., Busse, M., Freisinger, U. (2015). Regional Open Innovation Roadmapping: A New Framework for Innovation-Based Regional Development. Sustainability, Vol. 7, 2301-2321. DOI: 10.3390/su7032301.

6. Michelino, F, Cammarano, A., Lamberti, E., Caputo, M. (2015). Nowledge Domains, Technological Strategies and Open Innovation. Journal of Technology Management and Innovation, Vol. 10, No. 2, pp. 50-78. DOI: 10.4067/S0718-27242015000200005.

7. West, J., Salter, A., Vanhaverbeke, W., Chesbrough, H. (2014). Open Innovation: The Next Decade. Research Policy, Vol. 43, No. 5, pp. 805-811. DOI: 10.1016/j.respol.2014.03.001.

8. Boons, F. Montalvo, C. Quist, J. Wagner, M. (2013). Sustainable innovation, business models and economic performance: An overview. Journal of Cleaner Production, Vol. 45, pp. 1-8. DOI: 10.1016/j.jclepro.2012.08.013.

9. Arcese, G., Flammini, S., Lucchetti, M. C., Martucci, O. (2014). Open Sustainability Innovation in the Food Sector. Conference: The $4^{\text {th }}$ World Sustainability Forum Forum, Vol. 7, pp. 8067-8090. DOI: 10.3390/wsf-4-g001.

10. Cammarano, A., Caputo, M., Lamberti, E., Michelino, F. (2016). R\&D collaboration strategies for innovation: An empirical study through social network analysis. 
International Journal of Innovation and Technology Management, Vol. 14, No. 01, 1740001. https://doi.org/10.1142/S0219877017400016.

11. Andros S. V, Chang Shicao. Digitalization and Enterprises: New Trends of Innovative Development. Economic Journal of Odessa Polytechnic University. 2019/ № 4 (10). P. 5-13. DOI: 10.5281/zenodo.3757950. ULR: https://economics.opu.ua/410-2_print.

12. Boons, F., Lüdeke-Freund, F. (2012). Business Models for Sustainable Innovation: State of the Art and Steps Towards a Research Agenda. Journal of Cleaner Production, Vol. 45, pp. 9-19 (Special Issue Sustainable Innovation and Business Models). Available at SSRN: https://ssrn.com/abstract=2103495.

13. Schemmann, B., Herrmann, A. M., Chappin, M. M. H., Heimeriks, G. J. (2016). Crowdsourcing Ideas: Involving Ordinary Users in the Ideation Phase of New Product Development. Research Policy, Vol. 45, Issue 6, pp. 1145-1154. DOI: 10.1016/j.respol.2016.02.003.

14. Remer, D. S., Nieto, A. P. (1995). A Compendium and Comparison of 25 Project Evaluation Techniques. Part 1: Net Present Value and Rate of Return Methods, International Journal of Production Economics, Elsevier, Vol. 42, Issue 1, pp. 79-96. doi:10.1016/0925-5273(95)00104-2.

15. Schaltegger, S., Freund, F. L., Hansen, E. G. (2012). Business Cases for Sustainability: The Role of Business Model Innovation for Corporate Sustainability. International Journal of Innovation and Sustainable Development, Vol. 6, Issue 2, pp. 95-119. DOI: 10.1504/IJISD.2012.046944.

16. Von Hippel, E. (2005). Democratizing Innovation: The Evolving Phenomenon of User Innovation. Journal für Betriebswirtschaft, Vol. 55, pp. 63-78.

17. Von Hippel, E. (2010). Open User Innovation. Handbook of the Economics of Innovation, Vol. 1, pp. 411-427.

18. Grimaldi, M., Cricelli, L., Rogo, F. (2012). A Methodology to Assess Value Creation in Communities of Innovation. Journal of Intellectual Capital, Vol. 13, Issue 3, pp. 305-330. DOI: 10.1108/14691931211248882.

19. Cho, C., Lee, S. (2015). How Firms Can Get Ideas from Users for Sustainable Business Innovation, Sustainability, MDPI, Open Access Journal, Vol. 7, Issue 12, pp. 1-21. 16039-16059. https://doi.org/10.3390/su71215802.

20. Belderbos, R., Carree, M., Lokshin, B. (2004). Cooperative R\&D and Firm Performance. Research Policy, Vol. 33, No. 10, pp. 1477-1492. DOI: 10.1016/j.respol.2004.07.003.

21. Harrington, E. C. (1965). The Desirability Function. Industrial Quality Control, Vol. 21, pp. 494-498. 